\title{
Genotypic Diversity among Brazilian Isolates of Macrophomina phaseolina Revealed by RAPD
}

\author{
Álvaro M. R. Almeida ${ }^{1}$, Ricardo V. Abdelnoor ${ }^{1}$, Carlos A. Arrabal Arias ${ }^{1}$, Valdemar P. Carvalho ${ }^{2}$, David \\ S. Jacoud Filho ${ }^{3}$, Silvana R. R. Marin ${ }^{1}$, Luís C. Benato ${ }^{1}$, Mauro C. Pinto ${ }^{1}$ \& Cláudio G. P. Carvalho ${ }^{1}$ \\ ${ }^{1}$ Embrapa Soja, Cx. Postal 231, CEP 86001-970, Londrina, PR, Brazil, e-mail: almeida@cnpso.embrapa.br; ${ }^{2}$ Departmento de \\ Genética, Universidade Estadual de Londrina, CEP 86060-120, Londrina, PR, Brazil; ${ }^{3}$ Departamento de Agronomia, \\ Universidade Estadual de Ponta Grossa, CEP 84030-900, Ponta Grossa, PR, Brazil
}

(Aceito para publicação em 24/02/2003)

Corresponding author: Álvaro M. R. Almeida

ALMEIDA, A.M.R., ABDELNOOR, R.V., ARIAS, C.A.A., CARVALHO, V.P, JACOUD FILHO, D.S., MARIN, S.R.R., BENATO, L.C., PINTO, M.C. \& CARVALHO, C.G.P. Genotypic diversity among brazilian isolates of Macrophomina phaseolina revealed by RAPD. Fitopatologia Brasileira 28:279-285. 2003.

\begin{abstract}
Macrophomina phaseolina has been considered one of the most prevalent soybean (Glycine max) pathogens in Brazil. No genetic resistance has been determined in soybean and very little is known about the genetic diversity of this pathogen in tropical and sub-tropical regions. Fifty-five isolates from soybean roots were collected in different regions and analyzed through RAPD for genetic diversity. The UPGMA cluster analysis for 74 loci scored permitted identification of three divergent groups with an average similarity of $99 \%, 92 \%$ and $88 \%$, respectively. The three groups corresponded to $5.45 \%, 59.95 \%$ and $34.6 \%$, respectively of all isolates used. A single plant had three different haplotypes, while $10.9 \%$ of the analyzed plants had two different haplotypes. In another study the genetic similarity was evaluated among isolates from different hosts [soybean, sorghum (Sorghum bicolor), sunflower (Helianthus annuus), cowpea (Vigna unguiculata), corn (Zea

mays) and wheat (Triticum aestivum)] as well as two soil samples from native areas. Results showed that more divergent isolates originated from areas with a single crop. Isolates from areas with crop rotation were less divergent, showing high similarity values and consequently formed the largest group. Amplification of the ITS region using primers ITS 1 and ITS4 produced only one DNA fragment of $620 \mathrm{bp}$. None of the isolates were differentiated through PCR-RFLP. Our results demonstrated genetic variability among Brazilian isolates of $M$. phaseolina and showed that one single root can harbor more than one haplotype. Moreover, cultivation with crop rotation tends to induce less specialization of the pathogen isolates. Knowledge of this variation may be useful in screening soybean genotypes for resistance to charcoal rot. charcoal rot.
\end{abstract}

\section{RESUMO}

Diversidade genética entre isolados brasileiros de Macrophomina phaseolina, avaliada por RAPD

Macrophomina phaseolina é considerado como um dos fungos mais prevalecentes em infecções radiculares de soja, no Brasil. Nenhuma fonte de resistência genética foi ainda encontrada. Além disso, nenhuma informação foi obtida quanto à variabilidade genética deste patógeno, em regiões tropicais. Cinqüenta e cinco isolados de raízes de soja (Glycine Max), obtidos de diferentes regiões geográficas, foram analisados por RAPD para avaliação da diversidade genética. Análise de agrupamento (UPGMA), utilizando 74 loci, permitiu identificar três grupos, com uma média de $99 \%, 92 \%$ e $88 \%$ de similaridade genética, respectivamente. Os três grupos correspondem a 5,45\%,59,95\% e 34,6\% de todos os isolados utilizados. Apenas uma planta estava infetada por três diferentes haplotipos, enquanto $10,9 \%$ de todas as plantas estavam infetadas por haplotipos pertencentes a dois diferentes grupos. Em outro estudo a similaridade genética foi determinada entre isolados originários de diferentes hospedeiros [soja, sorgo (Sorghum bicolor), girassol (Helianthus annuus), caupi (Vigna unguiculata), milho (Zea mays) e trigo (Triticum aestivum)] e de duas amostras de solo de áreas virgens. Os resultados mostraram que isolados mais divergentes são oriundos de áreas com monocultura. Amplificação da região ITS produziram apenas um fragmento com $620 \mathrm{pb}$. Nenhum dos isolados foi diferenciado quando o produto amplificado por PCR foi digerido com enzimas de restrição. Os resultados demonstram a existência de variabilidade genética entre os isolados brasileiros de M. phaseolina e mostram que uma única raiz pode ter mais de um haplotipo. Além disso, a rotação de cultura induz menos diversidade genética entre os isolados. O conhecimento dessa variabilidade pode ser útil na seleção de genótipos resistentes à podridão de carvão.

\section{INTRODUCTION}

Macrophomina phaseolina (Tassi) Goid. infects roots of a wide range of crops causing charcoal rot. It is seedborne (Kunwar et al., 1986) and responsible for extensive problems worldwide. In Brazil, disease losses were reported in Southern States where $5 \%$ of the soybean [Glycine max (L.) Merril] fields were infected (Lehman et al., 1976).

Outbreaks are common in soybean fields where soybean is grown under water stress (Ferreira et al., 1979). Almost every soybean field harbors the pathogen, which is easily detected in the epidermal tissues of roots at the maturity stage during dry weather conditions. Therefore, disease is more prevalent in some years than in others. 
Control has not yet been achieved through resistance in spite of recent reports on tolerant genotypes (Smith and Carvil, 1997).

Little is known about the genetic complexity of this pathogen in Brazil and, only recently, research using molecular techniques has indicated genetic diversity among isolates. The first report of variability in morphological and virulence-based characters among isolates was made by Dhingra \& Sinclair (1973). Pearson et al. (1986) determined that isolates from corn (Zea mays L.) and soybean showed differences in sensitivity when grown in chlorate-containing medium.

Techniques such as random amplified polymorphic DNA (RAPD) analysis have contributed to our understanding of genetic variability in populations of M. phaseolina. According to Fuhlbohm (1997) genotypic diversity was clearly observed among Australian isolates of $M$. phaseolina from Vigna radiata. Recently, Su et al. (2001) reported that isolates from a given host were genetically similar but differed from those from other hosts. Moreover, they concluded that chloratesensitive isolates were genetically distinct from resistant ones.

Preliminary evidence of the occurrence of genetic diversity among Brazilian isolates came mainly from differences observed in colony morphology and growth rate. Later, RAPD analysis confirmed these findings (Almeida \& Abdelnoor, 1997).

Additional information regarding diversity within this pathogen should enhance the development and release of disease-resistant soybean cultivars and contribute to understanding the population biology of this organism.

The objective of this work was to determine the genetic diversity of Brazilian isolates of $M$. phaseolina in soybean fields and to evaluate the effect of crop rotation on this diversity.

\section{MATERIALANDMETHODS}

\section{Fungal isolates}

Soybean roots were collected from different states in Brazil (Table 1). Each root was thoroughly washed and dried at room temperature. Five small $0.5 \mathrm{~cm}$ epidermal section were excised from each root and sterilized in alcohol $(30 \mathrm{~s})$, transferred to $2.5 \%$ sodium hypochloride ( $30 \mathrm{~s}$ ) and washed in sterile water for $1 \mathrm{~min}$. Isolation was performed on potato dextrose agar (PDA) containing streptomycin $(0.1 \mathrm{mg} / \mathrm{ml})$. Plates were incubated at $26^{\circ} \mathrm{C}$ in the darkness for seven days. Small pieces of medium containing microesclerotia were collected and lightly ground in sterile water. A single microsclerotium was collected under the microscope and transferred to PDA slants. Fifty-five stock cultures were prepared using this method, for evaluation of genetic variability among geographical areas. Another study was set up to evaluate differences among M. phaseolina isolates from different hosts. Roots from corn, sorghum [Sorghum bicolor (L.) Moench] and wheat (Triticum aestivum L.) used in rotation with soybean or as single crop: common bean (Phaseolus vulgares L.), cowpea [Vigna unguiculata (L.) Walp] and sunflower (Helianthus annuus L.) (Table 2) were used. Additionally, two M. phaseolina isolates were included from soil samples: one from a natural forest where no crop was previously planted and the other from a coffee (Coofea arabica L.) field, both located at Londrina.

\section{DNA isolation}

Each isolate from the stock culture was grown in liquid potato-dextrose broth at $26^{\circ} \mathrm{C}$ for two weeks. Mycelia were centrifuged at 3,000 x g for $10 \mathrm{~min}$. Pellets were washed in sterile water and lightly squeezed in filter paper. Partially dried mycelium was stored at $-80^{\circ} \mathrm{C}$. These samples were later used for DNA extraction. Mycelium was crushed in liquid nitrogen and treated with hexadecyltrimethyl-ammonium bromide (CTAB) extraction buffer (50 mM Tris-HCl, pH 8,0, $700 \mathrm{mM}$ $\mathrm{NaCl}, 10 \mathrm{mM}$ EDTA, 10\% CTAB), followed by phenol/ chloroform purification and precipitation with ethanol. Samples were quantified for DNA concentration and stored at $-80^{\circ} \mathrm{C}$.

TABLE 1 - Isolates of Macrophomina phaseolina collected from different soybean (Glycine max) root plants and locations in soybean areas used in this study

\begin{tabular}{|c|c|c|c|c|c|}
\hline Isolate & $\begin{array}{c}\text { Plant/ } \\
\text { fragment }\end{array}$ & Haplotype & Isolate & $\begin{array}{c}\text { Plant/ } \\
\text { fragment }\end{array}$ & Haplotype \\
\hline 1 & P1/F2-RS* & 37 & 29 & P4/F5-MS & 15 \\
\hline 2 & P1/F3-RS & 23 & 30 & P5/F1-MS & 4 \\
\hline 3 & P1/F4-RS & 36 & 31 & P5/F2-MS & 15 \\
\hline 4 & P1/F5-RS & 35 & 32 & P5/F3-MS & 12 \\
\hline 5 & $\mathrm{P} 2 / \mathrm{F} 1-\mathrm{RS}$ & 24 & 33 & P5/F4-MS & 29 \\
\hline 6 & $\mathrm{P} 2 / \mathrm{F} 2-\mathrm{RS}$ & 24 & 34 & P5/F5-MS & 2 \\
\hline 7 & P2/F3-RS & 12 & 35 & P6/F1-MS & 10 \\
\hline 8 & $\mathrm{P} 2 / \mathrm{F} 4-\mathrm{RS}$ & 33 & 36 & P6/F2-MS & 12 \\
\hline 9 & P2/F5-RS & 33 & 37 & P6/F3-MS & 3 \\
\hline 10 & $\mathrm{P} 1 / \mathrm{F} 1-\mathrm{MS}$ & 2 & 38 & P6/F4-MS & 20 \\
\hline 11 & $\mathrm{P} 1 / \mathrm{F} 2-\mathrm{MS}$ & 1 & 39 & P6/F5-MS & 23 \\
\hline 12 & P1/F3-MS & 9 & 40 & $\mathrm{P} 1 / \mathrm{F} 1-\mathrm{RS}$ & 17 \\
\hline 13 & P1/F4-MS & 21 & 41 & P1/F2-PR & 16 \\
\hline 14 & P1/F5-MS & 22 & 42 & P1/F3-PR & 17 \\
\hline 15 & $\mathrm{P} 2 / \mathrm{F} 1-\mathrm{MS}$ & 34 & 43 & P1/F4-PR & 14 \\
\hline 16 & $\mathrm{P} 2 / \mathrm{F} 2-\mathrm{MS}$ & 6 & 44 & P1/F5-PR & 8 \\
\hline 17 & P2/F3-MS & 31 & 45 & P2/F1-PR & 11 \\
\hline 18 & $\mathrm{P} 2 / \mathrm{F} 4-\mathrm{MS}$ & 28 & 46 & P2/F2-PR & 7 \\
\hline 19 & P2/F5-MS & 12 & 47 & P2/F3-PR & 25 \\
\hline 20 & P3/F1-MS & 33 & 48 & P2/F4-PR & 18 \\
\hline 21 & P3/F2-MS & 10 & 49 & P2/F5-PR & 5 \\
\hline 22 & P3/F3-MS & 9 & 50 & $\mathrm{P} 1 / \mathrm{F} 1-\mathrm{MG}$ & 13 \\
\hline 23 & P3/F4-MS & 12 & 51 & $\mathrm{P} 2 / \mathrm{F} 1-\mathrm{MG}$ & 27 \\
\hline 24 & P3/F5-MS & 32 & 52 & $\mathrm{P} 2 / \mathrm{F} 2-\mathrm{MG}$ & 26 \\
\hline 25 & P4/F1-MS & 23 & 53 & $\mathrm{P} 2 / \mathrm{F} 3-\mathrm{MG}$ & 26 \\
\hline 26 & P4/F2-MS & 22 & 54 & $\mathrm{P} 2 / \mathrm{F} 4-\mathrm{MG}$ & 26 \\
\hline 27 & P4/F3-MS & 19 & 55 & $\mathrm{P} 2 / \mathrm{F} 5-\mathrm{MG}$ & 30 \\
\hline 28 & P4/F4-MS & 17 & & & \\
\hline
\end{tabular}

*P_/F_-ZZ where $\mathrm{P}_{-}=\#$ of plant root used; $\mathrm{F}_{-} \#$ of fragment of each root used for isolation; $\mathrm{ZZ}=$ State of collection $(\mathrm{MS}=$ Mato Grosso do Sul; $M G=$ Minas Gerais; $P R=$ Paraná; $R S=$ Rio Grande do Sul). In each group, isolates sharing $100 \%$ of similarity coefficient were considered the same haplotype. 
Genotypic diversity among brazilian isolates of Macrophomina phaseolina revealed by...

\section{RAPD analysis}

DNA from 55 M. phaseolina isolates was amplified by the RAPD method (Williams et al., 1990) using 22 random oligonucleotide (10-mer) primers (OPA-01, OPA-02, OPA-04, OPA-05, OPA-07, OPA-08, OPAB-01, OPAB-02, OPAB-03, OPAB-04, OPAC-01, OPAC-03, OPAD-02, OPB-01, OPM-02, OPM-10, OPM-15, OPP-04, OPP-14, OPS-16, OPU-07, OPX-15) (Operon Technologies, Inc., Alameda, CA, USA). Reactions were carried out in final volumes of $25 \mu \mathrm{l}$ containing $10 \mathrm{mM}$ of Tris-HCI ( $\mathrm{pH} 8.3$ ), $50 \mathrm{mM}$ of $\mathrm{KCl}, 2 \mathrm{mM}$ of $\mathrm{MgCl}_{2}, 100 \mu \mathrm{M}$ of each deoxynucleotide triphosphates (dATP, dTTP, dGTP and $\mathrm{dCTP}), 0.4 \mu \mathrm{M}$ of primer, one unit of Taq polymerase and $30 \mathrm{ng}$ of template DNA. Amplification was programmed for 45 cycles in a thermocycler (Perkin-Elmer, Norwalk, CT, USA). Each cycle consisted of a denaturation step at $94^{\circ} \mathrm{C}$ for $30 \mathrm{~s}$, a primer annealing step at $35^{\circ} \mathrm{C}$ for $30 \mathrm{~s}$, and a primer extension step at $72^{\circ} \mathrm{C}$ for $1 \mathrm{~min}$. Amplified fragments of DNA were resolved by electrophoresis on $1.3 \%$ agarose stained with ethidium bromide, and photographed under UV light (302 nm).

The resulting band patterns of each isolate were scored for the presence or absence of amplified products. Polymorphism in loci with faint bands was not scored. Data analysis were performed with the NTSYS program version $2.02 \mathrm{j}$ (Exeter Software, Setauket, NY, USA). The similarity coefficients for all possible pairs of isolates based on their fingerprint groups were estimated using the Dice coefficient. Dendrograms were constructed from the similarity coefficient data by the unweighted pair-group method with arithmetic averages (UPGMA) clustering.

How well the phenograms fit was determined by computing a cophenetic value matrix and comparing with the tree matrix (modules COPH and MXCOMP) from NTSYS. A cophenetic correlation $>0.9$ was considered a very good fit according to Mantel (1967). To evaluate the robustness of the groupings formed, the binary data set was subjected to bootstrapping using the WinBoot software program (Yap \& Nelson, 1996). The phenogram was reconstructed 1,000 times by repeated sampling with replacement and the frequency with which groups formed was used to indicate the strength of the groups.

A two-dimensional and three-dimensional principal coordinates analysis were constructed to provide another means of testing relationships among isolates using the EIGEN programs (NTSYS).

\section{ITS Amplifications and PCR-RFLP}

Nine isolates (20, 23, 33, 45, 57, 58, 61, 62 and 70) were randomly chosen for this study. The $5.8 \mathrm{~S}$ ribosomal DNA gene, and the internal transcribed spacer (ITS) region were amplified by polymerase chain reaction (PCR) in $50 \mu \mathrm{l}$ reactions performed in $10 \mathrm{mM}$ Tris- $\mathrm{HCl} \mathrm{pH} 8.3$ containing $50 \mathrm{mM} \mathrm{KCl}, 1.2$ $\mathrm{mM} \mathrm{MgCl}, 0.1 \%$ triton, $200 \mu \mathrm{M}$ of each of the four deoxyribonucleotide triphosphates, $0.34 \mu \mathrm{M}$ of each primer, 1 U Taq polymerase and $10 \mathrm{ng}$ of genomic DNA. The pair of primers used was designed according to the sequences published by White et al. (1990) and were named ITS 1 (5'TCCGTAGGTGAACCTGCGG-3') and ITS 4 (5'-TCCTCCGCTT ATTGATATGC-3') for the reverse and forward primers, respectively. Cycling conditions were $94{ }^{\circ} \mathrm{C}$ for DNA denaturation, $5 \mathrm{~min}$ for the first cycle and $1 \mathrm{~min}$ for the remaining cycles, $55^{\circ} \mathrm{C}$ for $1 \mathrm{~min}$ for primer annealing, and $72^{\circ} \mathrm{C}$ for $2 \mathrm{~min}$ for primer extension with a total of 35 cycles. Amplified products were analyzed by electrophoresis in $1.3 \%$ agarose gel and visualized after staining with ethidium bromide. Amplified products were digested with restriction enzymes (Apa I, Era I, Dra I, Sma I, Pru II, Hae III, Mbo I, Nde II, Eco RV and Taq I), according to the manufacturer's recommendations. The restriction fragments were separated by electophoresis in a $3 \%$ resolution agarose gel in TBE buffer.

\section{RESULTS}

The first experiment assessed the genetic variability among M. phaseolina soybean isolates from the same roots and from different roots collected at different geographic areas. The RAPD analysis was based on 74 polymorphic bands obtained with 22 primers. The UPGMA clustering produced a dendrogram that separated the 55 isolates into three groups at an arbitrary level of $70 \%$ similarity (Figure 1).

In each group, isolates sharing $100 \%$ of similarity coefficient were considered the same haplotype. Therefore, group 1, 2 and 3 were constituted by 2, 21 and 14 haplotypes,

TABLE 2 - Isolates of Macrophomina phaseolina collected from roots of different plant species

\begin{tabular}{lcclcc}
\hline \hline Isolate & Host & Origin & Isolate & Host & Origin \\
\hline 56 & Soybean & Realeza - PR & 66 & Bean & Cristalina - GO \\
57 & Sunflower & Londrina - PR & 67 & Cowpea & Fortaleza - CE \\
58 & Corn & Londrina - PR & 68 & Cowpea & Fortaleza - CE \\
59 & Soybean & Dourados - MS & 69 & Sunflower & Montividiu - GO \\
60 & Cowpea & Fortaleza - CE & 70 & Wheat & Londrina - PR \\
61 & Soybean & Uberaba - MG & 71 & Wheat & Londrina - PR \\
62 & Sorghum & Ribeirão Preto - SP & 72 & Wheat & Londrina - PR \\
63 & Sorghum & Ribeirão Preto - SP & 73 & Sunflower & Capitão Bicaco - RS \\
64 & Bean & Santo Ant. Goiás - GO & 74 & Soil/ Native & Alvorada do Sul - PR \\
65 & Bean & Barreiras - BA & 75 & Soil/Coffee & Bela Vista Paraíso - PR \\
\hline
\end{tabular}


respectively (Table 3 ).

The first group consisted of only three isolates and exhibited an average similarity of 0.99 , calculated from the similarity matrix. Two of the isolates (P1/F1-MS and P1/F2MS) did not cluster together with other isolates from the same root (P1/F3-MS, P1/F4-MS and P1/F5-MS) showing that the same root harbors distinct haplotypes. The third isolate, also included in group 1 and designated P5/F5-MS did not cluster with isolates from other fragments obtained from the same root (P5/F1-MS, P5/F2-MS, P5/F3-MS and P5/F4-MS). The second group had the largest number of haplotypes (21) identified among 33 isolates that exhibited an average similarity of $93 \%$. The third group with 14 haplotypes had an average similarity of $89 \%$ (Table 3 ).

One important point observed in this study was the occurrence of two very distinct haplotypes in the same root. For instance, roots from plant P1 or P2, collected in the State of Rio Grande do Sul have haplotypes classified in two distinct groups (2 and 3). Moreover, one plant collected in the State of Mato Grosso (P5) showed three different haplotypes in only one root.

The dendrogram was supported by either a bootstrap analysis with high bootstrap values for groups or by a cophenetic correlation coefficient of 0.98 , considered a very good value. An additional analysis through principal coordinate analysis confirmed the same cluster profile with $81.0 \%$ of the total variance explained by the first two coordinates (Figure 2).

The second experiment evaluated the genetic diversity among isolates of $M$. phaseolina collected from different hosts in different areas. A total 221 polymorphic bands originated from the same 22 primers used before. Based on the similarity values, a matrix of similarity was obtained (Table 4). The UPGMA clustering was conducted to graphically display the possible groups. At 55\% similarity the analysis permitted clustering of the isolates in six groups (Figure 3 ). The cut value used in the dendrogram was chosen after a previous evaluation of the principal coordinates analysis that confirmed the clustering groups with $58 \%$ of total variance explained by the first three coordinates (Figure 4). In addition, a bootstrap analysis with high values for each cluster and a cophenetic correlation of 0.96 supported this grouping. There were discrete groups in both figures. Groups 1 and 2 were constituted only by one isolate: from sunflower and from cowpea, respectively. Group 3 had isolates of common bean and sorghum. Group 4 had two other isolates from cowpea. Group 5, the largest group was constituted by isolates originating from an area alternatively cropped with soybean while group 6 also had isolates from corn, sunflower and soybean. Isolates 74 and 75, from soil samples collected at a native area without any previous crop in its history were classified in groups 5 and 6 , respectively. Isolate 60 from cowpea roots classified in group 2 showed a small similarity of $33 \%$ and $22 \%$ with two other cowpea isolates (67 and 68, respectively) classified in group 4 . The same is true for isolates from sunflower. Isolate 69 , from a central area of Brazil was only $56 \%$ and $46 \%$ similar to isolates 57 and 73 , respectively, suggesting that isolates from the same host but

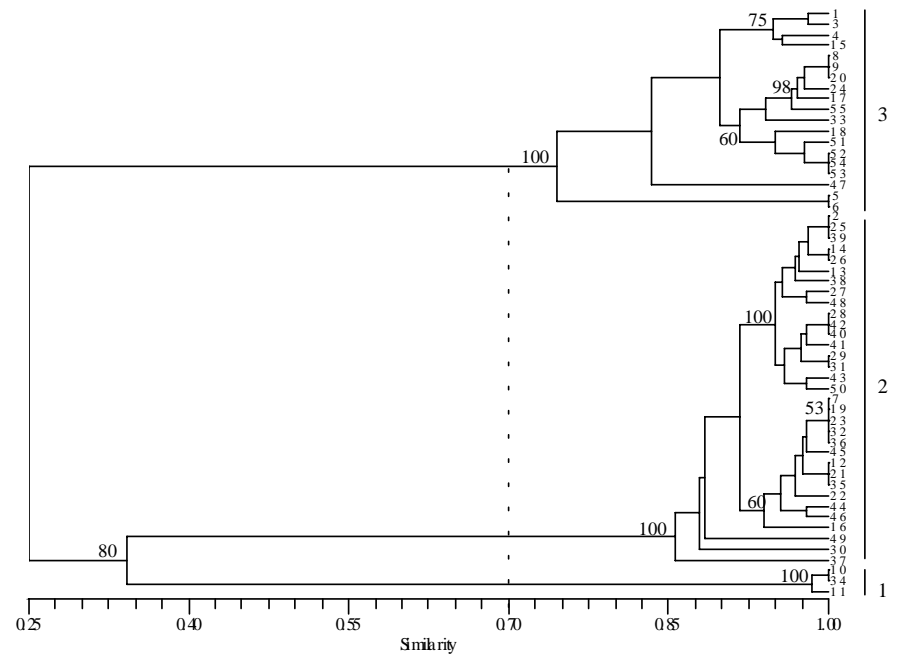

FIG. 1 - Dendrogram constructed with UPGMA clustering method among 55 isolates of Macrophomina phaseolina. Similarities were computed from 74 random amplified polymorphic DNA loci. The scale in the dendrogram is the genetic similarity coefficient calculated according to Dice (1945). Numbers at the nodes represent boostrap generated by 1,000 replications using the program WinBoot (Yap and Nelson, 1996). Only boostrap values of 50\% or greater are shown.

from different areas are more distant in terms of genetic similarity (Table 4)

Using the specific primers ITS 1 and ITS 4, only a single band of $620 \mathrm{bp}$ was generated in the amplification pattern of all the isolates. Digested fragments were obtained only with Taq I (298 bp and 246 bp), Eco RV (324 bp and 300 bp), Mbo I (321 bp, 209 bp and 81 bp) and, Nde II (347 bp, 198 bp), but no polymorphism was observed among all the isolate profiles. Reproducibility was demonstrated by replicate tests for all isolates.

\section{DISCUSSION}

This is the first study on genetic diversity among isolates of M. phaseolina in Brazil and complements previous results obtained by Almeida \& Abdelnoor (1998). The results showed a low genetic diversity among most of the soybean isolates of

TABLE 3 - Random amplified polymorphic DNA (RAPD) diversity observed among 55 isolates of Macrophomina phaseolina by UPGMA* cluster analysis

\begin{tabular}{lccc}
\hline \hline & Group 1 & Group 2 & Group 3 \\
\hline $\mathrm{N}^{\circ}$ loci scored & 74 & 74 & 74 \\
$\mathrm{~N}^{\circ}$ isolates & 3 & 33 & 19 \\
$\mathrm{~N}^{\circ}$ haplotypes & 2 & 21 & 14 \\
Average similarity (\%) & 99.0 & 93.0 & 89.0 \\
Range similarity (\%) ** & $0.98-1.00$ & $0.85-0.94$ & $0.77-0.91$
\end{tabular}

*Unweighted pair-group method with arithmetic averages (Figure1). ** Values calculated from the similarity matrix (not shown). 
Genotypic diversity among brazilian isolates of Macrophomina phaseolina revealed by...

M. phaseolina inside each group. However, divergence among groups is high. Low genetic variability is usually observed in populations of fungi that do not reproduce sexually as occur with M. phaseolina. Although there is no proof of heterokaryotic condition of the mycelia based on ITS analysis, it is possible to affirm that parasexualism with fusion of cells from different hyphae may form heterokaryons that contribute to the variation identified.

However, the identification of different haplotypes in the same root became a very interesting point to be considered in future breeding programs. The presence of two different haplotypes in plants P1, P2 from the State of Minas Gerais, plants P4 and P6 from the State of Mato Grosso and plant P1 from the State of Parana clearly show that this is not a rare event. Moreover, plant P5/F5-MS had three different haplotypes suggesting that diversity is geographically possible in the same area, detectable depending on the sampling methodology and size.

The high similarity observed among isolates from different regions is a strong evidence suggesting that the isolates used in this work did not evolve independently from each other and, therefore, may be considered as part of the same ancestral population. Isolates from the state of Rio Grande do Sul, Paraná, Minas Gerais and Mato Grosso were included in the same cluster. The strength of this affirmative is supported by the three different analyses: clustering dendrogram, bootstrapping and cophenetic coefficient.

As soybean cultivation in Brazil began in the southern states, spreading to northern regions, this is a logical conclusion, especially because this fungus is seed transmitted (Andrus, 1938). However, we cannot ignore the genetic diversity of native populations of $M$. phaseolina naturally found in "virgin" soils that through the years have infected

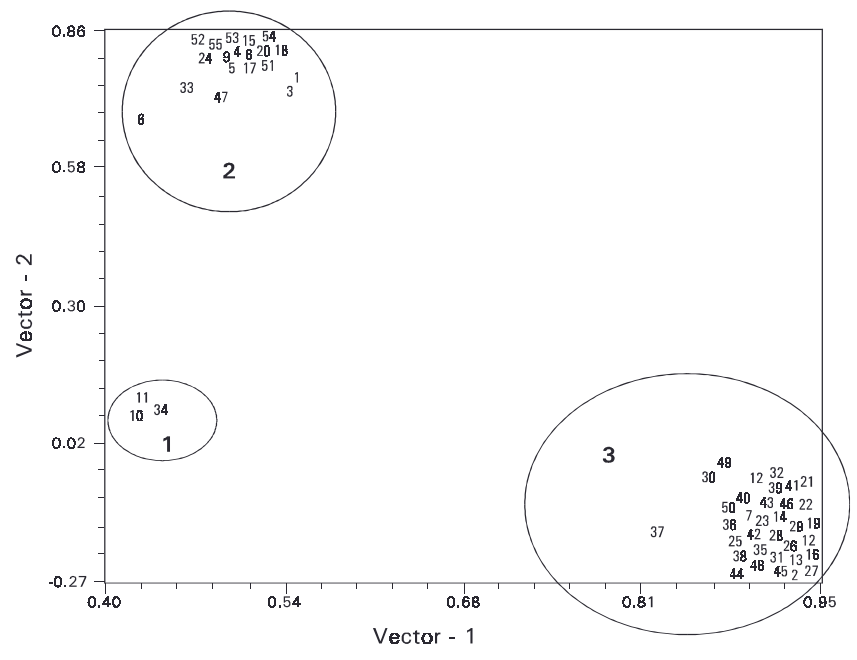

FIG. 2 - Two-dimensional principal coordinates plot of 55 Macrophomina phaseolina isolates based on differences in random amplified polymorphic DNA fingerprints. Note the formation of three clusters. commercial crops as soon as these soils were used for commercial purpose. Additional research should try to evaluate genetic diversity within populations of this fungus collected in soils with native vegetation.

In contrast to the first study, the comparison of the genetic similarity of isolates from different hosts used or not in rotation with soybeans exhibited lower similarity values showing a larger diversity among isolates. Clusters that contained soybean isolates were formed mainly by isolates from areas with a history of soybean production (clusters 5 and 6). All clusters that did not contain soybean isolates were from areas without any soybean crop history. A principal component analysis strongly supported these clusters. Isolates from soil samples were clustered with soybean isolates in a three-vector analysis. Considering the migration of soybean in Brazil and the fact that this fungus is seed borne, it is possible to conclude that native soil isolates may be the ancestors of the haplotypes identified in soybean fields sampled for this work. It is important to consider that soil samples were collected only in areas located close to Londrina, state of Paraná. Intensive sampling should be conducted in most of the new and old areas to determine the gene flow among population of this fungus, in Brazil. Common bean and cowpea are not normally used in crop rotation with soybean, and as expected their isolates did not cluster with soybean isolates. Moreover, one isolate designated 69, was the only one from a native area cultivated for the first time with sunflower in the central part of the country. This isolate was the most genetically divergent and constituted a single group. These observations show that some isolates may become less specialized as more crops are cultivated in the same area. Or, host selection may be the evolutionary force responsible for the observed genetic differentiation among isolates from different hosts.

At this point, it is important to mention that host specialization with $M$. phaseolina was first described by Pearson et al. (1986) suggesting that isolates from one specific host are more suited to colonize it. Later, Cloud \& Rupe (1991) working with isolates of soybean and sorghum, also observed differences in pathogenicity. Recently, another report mentioned the same fact but with isolates from soybean, sorghum and cotton (Gossypium hirsutum L.) (Su et al., 2001). Isolates were clearly grouped according to the host origin. Additionally, the authors did not observe any molecular variation among the isolates tested in PCR-RFLP of the ITS region.

Restriction analysis of the ITS region did not prove to be a suitable method for detecting variability among $M$. phaseolina isolates, thus confirming the results of $\mathrm{Su}$ et al. (2001).

In our study, genetic diversity was observed among isolates from the same as well as different areas, showing that in areas recently cultivated with soybeans one can find the same haplotypes found in traditional growing areas. This fact may be explained by the capacity of this fungus to be seed transmitted (Andrus, 1938). Genetic diversity among isolates from different native soils is still under investigation, but results from this study show that two isolates were classified as 
A.M.R. Almeida et al.

TABLE 4 - Similarity matrix for 20 isolates of Macrophomina phaseolina from different plant species, calculated using the Dice coefficient

\begin{tabular}{|c|c|c|c|c|c|c|c|c|c|c|c|c|c|c|c|c|c|c|c|}
\hline & 56 & 59 & 61 & 64 & 65 & 66 & 60 & 67 & 68 & 57 & 69 & 73 & 70 & 71 & 72 & 62 & 63 & 58 & $\begin{array}{ll}74 & 7\end{array}$ \\
\hline 56 & 1 & & & & & & & & & & & & & & & & & & \\
\hline 57 & 0.8571 & 1 & & & & & & & & & & & & & & & & & \\
\hline 61 & 0.4528 & 0.4959 & 1 & & & & & & & & & & & & & & & & \\
\hline 64 & 0.3119 & 0.3710 & 0.3840 & 1 & & & & & & & & & & & & & & & \\
\hline 65 & 0.3200 & 0.3826 & 0.3276 & 0.7059 & 1 & & & & & & & & & & & & & & \\
\hline 66 & 0.4404 & 0.4516 & 0.8320 & 0.3594 & 0.3193 & 1 & & & & & & & & & & & & & \\
\hline 60 & 0.3303 & 0.3387 & 0.3360 & 0.5938 & 0.5210 & 0.3750 & 1 & & & & & & & & & & & & \\
\hline 67 & 0.4038 & 0.4706 & 0.4833 & 0.2764 & 0.2807 & 0.4553 & 0.3252 & 1 & & & & & & & & & & & \\
\hline 68 & 0.2857 & 0.3284 & 0.3852 & 0.2319 & 0.1550 & 0.4203 & 0.2319 & 0.5865 & 1 & & & & & & & & & & \\
\hline 57 & 0.6557 & 0.7153 & 0.4928 & 0.3688 & 0.3333 & 0.5390 & 0.3688 & 0.4559 & 0.3311 & 1 & & & & & & & & & \\
\hline 69 & 0.4324 & 0.4444 & 0.3622 & 0.5231 & 0.4628 & 0.3692 & 0.5077 & 0.3200 & 0.2571 & 0.4615 & 1 & & & & & & & & \\
\hline 73 & 0.4464 & 0.4567 & 0.7969 & 0.3664 & 0.2951 & 0.8397 & 0.3206 & 0.4444 & 0.3972 & 0.5556 & 0.3759 & 1 & & & & & & & \\
\hline 70 & 0.5045 & 0.5397 & 0.8189 & 0.4000 & 0.3636 & 0.8615 & 0.3538 & 0.4480 & 0.4000 & 0.6014 & 0.4091 & 0.8421 & 1 & & & & & & \\
\hline 71 & 0.4259 & 0.4715 & 0.8065 & 0.3622 & 0.3051 & 0.8031 & 0.3150 & 0.4262 & 0.4088 & 0.5571 & 0.3721 & 0.8154 & 0.9147 & 1 & & & & & \\
\hline 72 & 0.5273 & 0.5440 & 0.8254 & 0.4341 & 0.3667 & 0.8217 & 0.3566 & 0.4355 & 0.3885 & 0.5775 & 0.4275 & 0.8333 & 0.8855 & 0.8594 & 1 & & & & \\
\hline 62 & 0.3119 & 0.3710 & 0.3680 & 0.7344 & 0.7563 & 0.3594 & 0.4844 & 0.3252 & 0.2609 & 0.3404 & 0.5077 & 0.3511 & 0.4154 & 0.3780 & 0.4341 & 1 & & & \\
\hline 63 & 0.3396 & 0.3802 & 0.3770 & 0.7040 & 0.7586 & 0.3520 & 0.4640 & 0.3000 & 0.2370 & 0.3333 & 0.5354 & 0.3594 & 0.4094 & 0.3871 & 0.4286 & 0.9440 & 1 & & \\
\hline 58 & 0.7523 & 0.8065 & 0.5120 & 0.3438 & 0.3361 & 0.5156 & 0.3281 & 0.5041 & 0.3333 & 0.8085 & 0.4308 & 0.5344 & 0.6000 & 0.5354 & 0.6202 & 0.3594 & 0.3520 & 1 & \\
\hline 74 & 0.4762 & 0.4833 & 0.8099 & 0.3387 & 0.2957 & 0.7903 & 0.3065 & 0.4370 & 0.4030 & 0.4818 & 0.3651 & 0.8189 & 0.7460 & 0.7154 & 0.8160 & 0.3548 & 0.3802 & 0.5645 & 1 \\
\hline 75 & 0.7664 & 0.8361 & 0.5041 & 0.3333 & 0.3248 & 0.5079 & 0.3175 & 0.4959 & 0.3088 & 0.8058 & 0.4219 & 0.5271 & 0.5781 & 0.5280 & 0.5984 & 0.3492 & 0.3577 & 0.9524 & 0.5574 \\
\hline
\end{tabular}

different haplotypes and established in different clusters.

Macrophomina phaseolina is known to occur throughout Brazil. Because the perfect stage has not yet been observed in the remaining of infected roots, the pathogen has been presumed to be disseminated in the vegetative state. The fact that distinct locations show isolates with indistinguishable

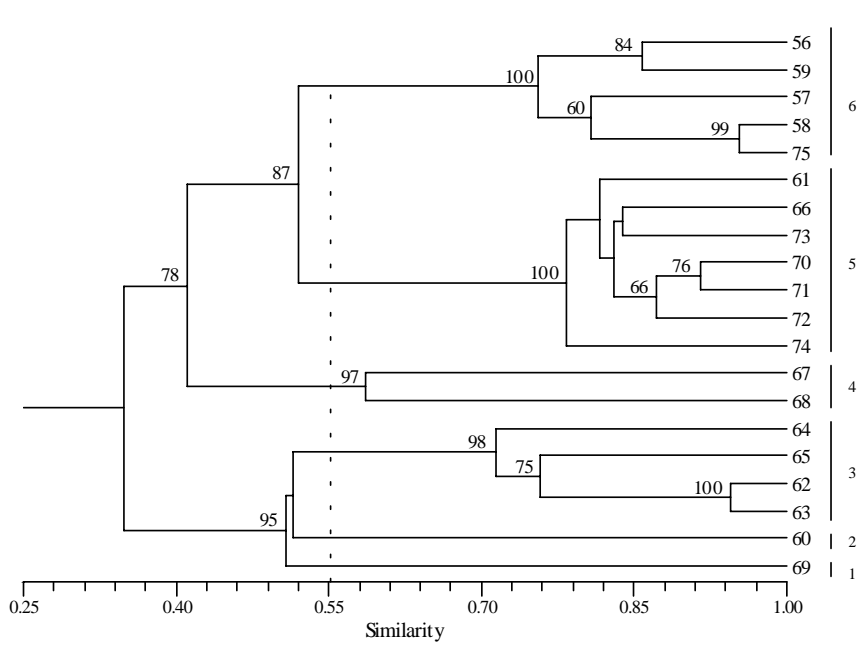

FIG. 3 - Dendrogram constructed with UPGMA clustering method among 20 isolates of Macrophomina phaseolina isolated from different hosts and soil. Similarities were computed from 226 random amplified polymorphic DNA loci. The scale in the dendrogram is the genetic similarity coefficient calculated according to Dice (1945). Numbers at the nodes represent boostrap generated by 1,000 replications using the program WinBoot. Only boostrap values of $50 \%$ or greater are shown. Isolates and hosts: $64,65,66=$ common bean; $58=$ corn; $60,67,68=$ cowpea; $69,73=$ sunflower; 74 and $75=$ soil samples from native areas; $62,63=$ sorghum; $56,57,59,61=$ soybean; $70,71,72=$ wheat. Dark numbers refer to the groups.
RAPD patterns suggests that some isolates may have migrated recently between locations. Such movement could have occurred by seeds, contaminated equipment or soil infected with sclerotia. In summary, our results demonstrated that RAPD markers are suitable for measuring genetic relatedness, detecting variation within and between $M$ phaseolina

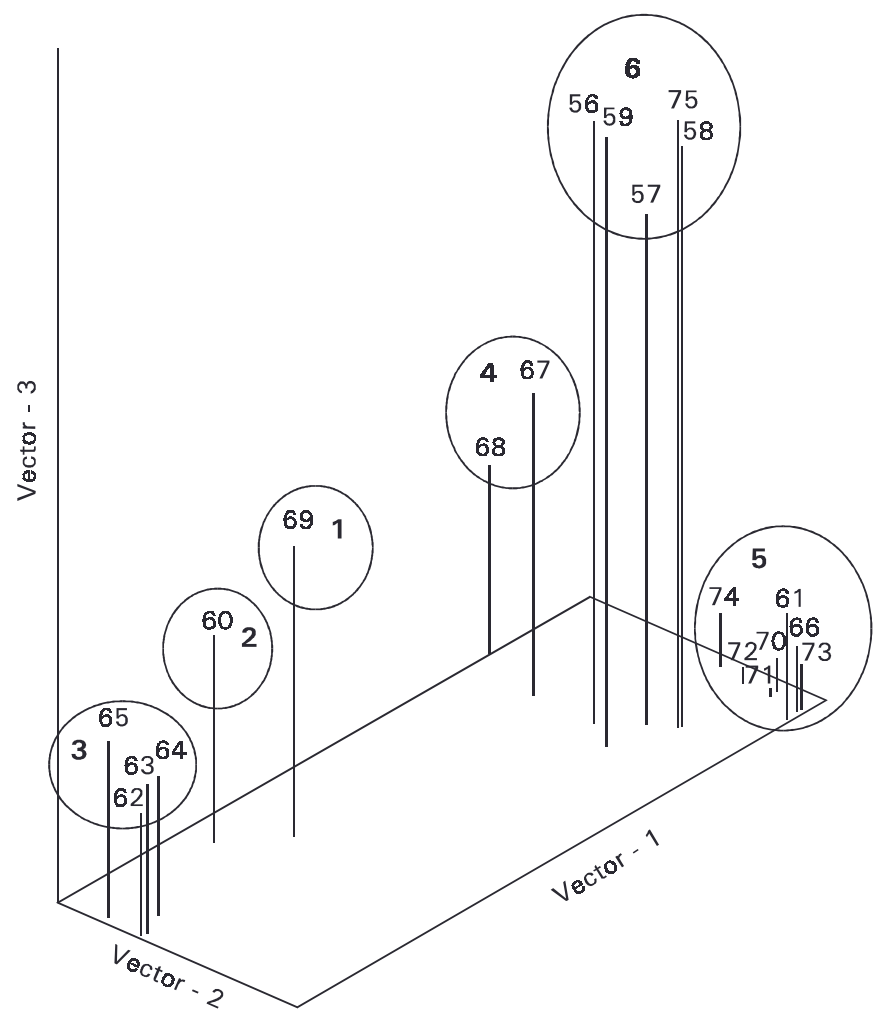

FIG. 4 - Three-dimensional principal coordinates plot of 20 Macrophomina phaseolina isolates based on differences in random amplified polymorphic DNA fingerprints. Note the formation of six clusters. 
Genotypic diversity among brazilian isolates of Macrophomina phaseolina revealed by...

population, and help to understand the ecology and biology of this fungus. Variability in the pathogen population may reflect the lack of resistance among current commercial soybean genotypes.

\section{ACKNOWLEDGEMENTS}

We are grateful to the following sample collectors: Dr. Neylson Arantes, Jeferson L. S. Costa, Alexandre S. Ferreira, Leila Costamilan, Fernando A. Paiva, J. A. de A. Lima, Maria N. G. Pessoa and Dario Hiromoto. We thank Dr. Marisa A. S. V. Ferreira (UnB), Dr. Robert Miller (PUC-Brasilia), Dr. Everaldo Barros (UFV) and Dr. José F. F. Toledo (Embrapa Soja) for critical reading of the manuscript and valuable suggestions. This project was approved for publication by the head of Research and Development of Embrapa Soja as manuscript number 07/2002.

\section{LITERATURE CITED}

ALMEIDA, A.M.R. \& ABDELNOOR, R.V. Variabilidade genética de isolados de Macrophomina phaseolina, coletados em diferentes regiões do Brasil. $1^{0}$ Encontro Paranaense de Biotecnologia Aplicada à Agropecuária. Londrina. p.97. 1998.

ANDRUS, C.F. Seed transmission of Macrophomina phaseoli. Phytopathology 28:620-634. 1938.

CLOUD, G.L. \& RUPE, J.C. Morphological instability on a chlorate medium of isolates of Macrophomina phaseolina from soybean and sorghum. Phytopathology 81:892-895. 1991.

DHINGRA, O.D. \& SINCLAIR, J.B. Location of Macrophomina phaseolina on soybean plants related to culture characteristics and virulence. Phytopathology 63:934-936. 1973.

DICE, L.R. Measures of the amount of ecological association between species. Ecology 26:297-302. 1945.

FERREIRA, L.P., LEHMAN, P.S. \& ALMEIDA, A.M.R. Doenças da soja no Brasil. Circular Técnica no. 1. CNPSo. EMBRAPA. 1979. FUHLBOHM, M. Genotypic diversity among Australian isolates of Macrophomina phaseolina. XX Biennial Australian Plant Pathology Society Conference, Lincoln University, New Zeland. p.52. 1997.

KUNWAR, I.K., SINGH, T., MACHADO, C.C. \& SINCLAIR, J.B. Histopathology of soybean seed and seedling infection by Macrophomina phaseolina. Phytopathology 76:532-535. 1986.

LEHMAN, P.S., MACHADO, C.C. \& TARRAGÓ, M.T. Frequiência e severidade de doenças de soja nos estados do Rio Grande do Sul e Santa Catarina. Fitopatologia Brasileira 1:183-193. 1976.

MANTEL, N. A. The detection of disease clustering and a generalized regression approach. Cancer Research, 27:209-220. 1967.

PEARSON, C.A.S., LESLIE, J.F. \& SCWENK, F.W. Variable chlorate resistance in Macrophomina phaseolina from corn, soybean and soil. Phytopathology 76:646-649. 1986.

SMITH, G.S. \& CARVIL, O.N. Field screening of commercial and experimental soybean cultivars for their reaction to Macrophomina phaseolina. Plant Disease 81:363-368. 1997.

SU, G., SUH, S.O., SCHNEIDER, R.W. \& RUSSIN, J.S. Host specialization in the charcoal rot fungus, Macrophomina phaseolina. Phytopathology 91:120-126. 2001.

WILLIAMS, J.G.K., KUBELIK, A.R., LIVAK, K.J., RAFALSKI, J.A. \& TINGEY, S.V. DNA polymorphism amplified by arbitrary primers are useful as genetic markers. Nucleic Acids Research 18:65316535. 1990.

WHITE, T.J., BRUNS, T., LEE, S. \& TAYLOR, J.W. Amplification and direct sequencing of fungal ribosomal RNA genes for phylogenetics. In: Innis, M.A., Gelfand, D.H., Sninskey, J.J. \& White, T.J. (Eds.) PCR protocols: A guide to methods and applications. Academic Press, San Diego.1990. pp.315-322.

YAP, I. \& NELSON, R. J. Winboot: A program for performing boostrap analysis of binary data to determine the confidence limits of UPGMAbased dendrograms. IRRI Discussion Paper Series 14. International Rice Research Institute, Manila, Philipines. 1996. 